\title{
ESTIMASI SERAPAN KARBON MANGROVE MELALUI PROSES FOTOSINTESIS DI TAMAN NASIONAL BERBAK-SEMBILANG
}

\section{ESTIMATION OF MANGROVE CARBON ABSORPTION BY PHOTOSYNTHESIS MECHANISM IN BERBAK-SEMBILANG NATIONAL PARK}

\author{
Tengku Zia Ulqodry ${ }^{1}$, Apri Suganda ${ }^{1}$, Andi Agussalim¹, Riris Aryawati ${ }^{1}$ \& Afan Absori ${ }^{2}$ \\ ${ }^{1}$ Jurusan Ilmu Kelautan, Fakultas MIPA, Universitas Sriwijaya, Sumatera Selatan \\ ${ }^{2}$ SPTN Wilayah 2, Taman Nasional Berbak-Sembilang, Sumatera Selatan \\ e-mail : zia_uul@unsri.ac.id \\ Diterima tanggal: 11 Juli 2020; diterima setelah perbaikan: 25 Agustus 2020 ; Disetujui tanggal: 26 Agustus 2020
}

\begin{abstract}
ABSTRAK
Mangrove merupakan ekosistem terbesar yang terdapat di kawasan Taman Nasional Berbak-Sembilang (TNBS) wilayah Sumatera Selatan. Mangrove memiliki kemampuan menyerap gas karbondioksida melalui fotosintesis dan selanjutnya disimpan dalam biomasa yang dikenal juga sebagai sink karbon. Penelitian ini bertujuan untuk menduga kemampuan daya serap karbon melalui proses fotosintesis di kawasan mangrove TNBS Sumatera Selatan. Penelitian ini telah dilaksanakan pada bulan Juli - Agustus 2017, di 12 titik stasiun pengamatan. Kemampuan daya serap karbon mangrove melalui fotosintesis diduga dengan pendekatan metode Leaf Area Index (LAI), terhadap 14 jenis mangrove dominan di BNSP Sumatera Selatan. Jumlah rata-rata serapan karbon vegetasi mangrove melalui proses fotosintesis di TNBS Sumatera Selatan sebesar 204,91 kg/ha/hari. Avicennia marina dan Rhizophora apiculata merupakan komunitas tertinggi yang mampu menyerap karbon melalui proses fotosintesis dengan serapan mencapai 553,43 kg-C/ha/hari dan 401,99 kg-C/ha/hari. Adapun secara individual, Bruguiera cylindrica merupakan jenis mangrove yang memiliki kemampuan menyerap karbon terbesar melalui fotosintesis $(10,95 \mathrm{~kg}-\mathrm{C} / \mathrm{ha} /$ hari). Dari sisi kemampuan serapan karbon melalui fotosintesis, jenis A. marina, R. apiculata dan B. cylindrica dianjurkan sebagai tanaman restorasi dengan tujuan peningkatan sink karbon di kawasan mangrove TNBS Sumatera Selatan.
\end{abstract}

Kata kunci: Serapan Karbon, Mangrove, Fotosintesis, Taman Nasional Berbak-Sembilang.

\section{ABSTRACT}

Mangrove is the largest ecosystem in Berbak-Sembilang National Park (BSNP) South Sumatra. Mangrove has capability to absorb carbon dioxide through photosynthesis then store it in biomass, that known as Carbon sink. The purpose of this research was to estimate the ability of carbon fixation through the photosynthesis mechanism in the mangrove area of BSNP South Sumatra. This study was conducted in July-August 2017, at 12 observation stations. Data of carbon fixation through photosynthesis was estimated by using Leaf Area Index (LAI) method. The estimation of carbon fixation by photosynthesis was done for 17 dominan mangrove species in BNSP South Sumatera. The average amount of carbon absorbed by mangrove vegetation through photosynthesis mechanism in BNSP South Sumatera was $204.91 \mathrm{~kg} / \mathrm{ha} /$ day. Avicennia marina and Rhizophora apiculata were the mangrove community that showed highest capability to absorb carbon through photosynthesis around $553.43 \mathrm{~kg} \mathrm{C/ha/day}$ and $401.99 \mathrm{~kg}-\mathrm{C} / \mathrm{ha} /$ day, respectively. Individually, B. cylindrica had the highest capability of carbon fixation by photosynthesis mechanism (10.95 kg-C/ha/day). Our research recommended three mangrove species (A. marina, R. apiculata and B. cylindrica) for restoration species to increase carbon sink in BNSP South Sumatera based on their photosinthesis performances.

Keywords: Carbon Absorption, Mangrove, Photosynthesis, Berbak-Sembilang National Park. 


\section{PENDAHULUAN}

Mangrove adalah tumbuhan yang biasa ditemukan pada daerah estuaria dan pantai yang landai dengan substrat berlumpur serta dipengaruhi oleh pasang surut air laut. Mangrove merupakan ekosistem peralihan antara darat dan laut serta dikenal mempunyai berbagai peran yang sangat penting, baik secara ekologis maupun ekonomis (Prihadi et al., 2018; Suniada \& Aden, 2019).

Di lain sisi, ekosistem mangrove juga merupakan salah satu ekosistem pesisir yang menerima tekanan antropogenik yang besar. Alih fungsi lahan mangrove untuk kepentingan lainnya menunjukkan tren yang makin besar dari tahun ke tahun (Kepel et al., 2018). Akumulasi tekanan secara ekologis dikombinasikan dengan tekanan akibat kebutuhan ekonomis memerlukan adanya titik temu antara kelestarian dengan azas pemanfaatan demi keberlanjutan ekosistem mangrove di suatu kawasan.

Mangrove memiliki keunikan dan peranan penting sebagai tumbuhan utama di daerah pesisir tropis (Ulqodry et al., 2014). Arti penting mangrove ini akan lebih berarti, jika potensinya sebagai penyimpan karbon juga diketahui. Konsentrasi gas rumah kaca, terutama karbon di atmosfer dari waktu ke waktu terus meningkat yang memicu pemanasan global. Kemampuan daun mangrove untuk memproduksi $\mathrm{O}_{2}$ dan mengkonsumsi $\mathrm{CO}_{2}$ dengan baik merupakan mekanisme fundamental yang mendukung kondisi oksigen dan karbondioksida ekosistem dari tingkat individu menuju skala global (Ulqodry et al., 2016).

Mangrove adalah ekosistem yang kaya akan penyimpanan karbon dan memiliki peran dalam siklus karbon global. Aliran karbon dari atmosfir ke vegetasi merupakan aliran yang bersifat dua arah, yaitu pengikatan $\mathrm{CO}_{2}$ ke dalam biomasa melalui fotosintesis dan pelepasan $\mathrm{CO}_{2}$ ke atmosfer melalui proses respirasi, dekomposisi dan pembakaran. Proses penyerapan dari atmosfir melalui fotosintesis dan penyimpanannya berupa biomasa dalam stok karbon akhirnya membentuk rosot (sink) karbon.

Di Ekosistem pesisir, mangrove bersama-sama dengan ekosistem padang lamun dan salt marshes telah diidentikkan sebagai 'blue carbon sinks' bumi. Untuk alasan ini, mangroves telah dipertimbangkan sebagai carbon sink di ekosistem pesisir. Kapasitas mangrove yang tinggi untuk mengikat karbon (Cui et al., 2018) menunjukkan potensinya dalam program "Clean
Development Mechanism (CDM)" yang merupakan bagian dari Kyoto Protocol (Okimoto et al., 2007).

Ekosistem mangrove merupakan ekosistem utama dan dominan di kawasan Taman Nasional BerbakSembilang (TNBS) wilayah Sumatera Selatan. Kawasan mangrove TNBS juga merupakan kawasan mangrove terbesar di Indonesia wilayah barat (Suwignyo et al., 2012). Beberapa penelitian terdahulu di TNBS lebih fokus ke dalam karbon stok mangrove dalam bentuk biomassa dan di sedimen (Manuri et al., 2011; Sarno et al., 2020) Sampai dengan saat ini, belum ada informasi mengenai kemampuan daya serap mangrove terhadap karbon melalui proses fotosintesis di kawasan TNBS wilayah Sumatera Selatan.

Metode yang digunakan untuk melihat kemampuan daya serap gas karbondioksida dengan menggunakan metode Leaf Area Index (LAI) yakni menghitung laju fotosintesis bersih dari kanopi yang berada pada kawasan hutan mangrove di TNBS wilayah Sumatera Selatan. Metode pengukuran ini bersifat non-destruktif.

Dalam upaya menjaga kelestarian mangrove, maka sejak dini perlu diketahui potensi serapan karbon (carbon sink) yang dimiliki oleh mangrove, baik mangrove alami maupu dari hasil restorasi. Hasil penelitian ini nantinya diharapkan dapat dijadikan sebagai bahan pertimbangan untuk pengambilan kebijakan dalam pengelolaan kawasan mangrove TNBS wilayah Sumatera Selatan serta dapat dijadikan informasi pendukung untuk penelitian di kawasan tersebut.

\section{BAHAN DAN METODE}

\section{Lokasi Penelitian}

Penelitian ini telah dilaksanakan pada 22 - 29 Juli 2017 dan 18 - 21 Agustus 2017 di kawasan mangrove Taman Nasional Berbak Sembilang wilayah Sumatera Selatan. Pengukuran dilakukan di 12 titik stasiun pengamatan, yang merupakan representasi dari 3 kawasan mangrove TNBS Sumatera Selatan, yakni daerah Barong dan sekitarnya, Sembilang dan sekitarnya, serta Tanah Pilih dan sekitarnya (Gambar 1).

\section{Pengambilan Data Vegetasi Mangrove dominan}

Untuk melakukan pendugaan serapan karbon mangrove perlu dilakukan terlebih dahulu analisis vegetasi mangrove dominan yang ada di lokasi penelitian. Metode penentuan vegetasi mangrove dominan dilakukan dengan cara membuat transek kuadrat. Vegetasi mangrove yang diukur adalah yang termasuk 


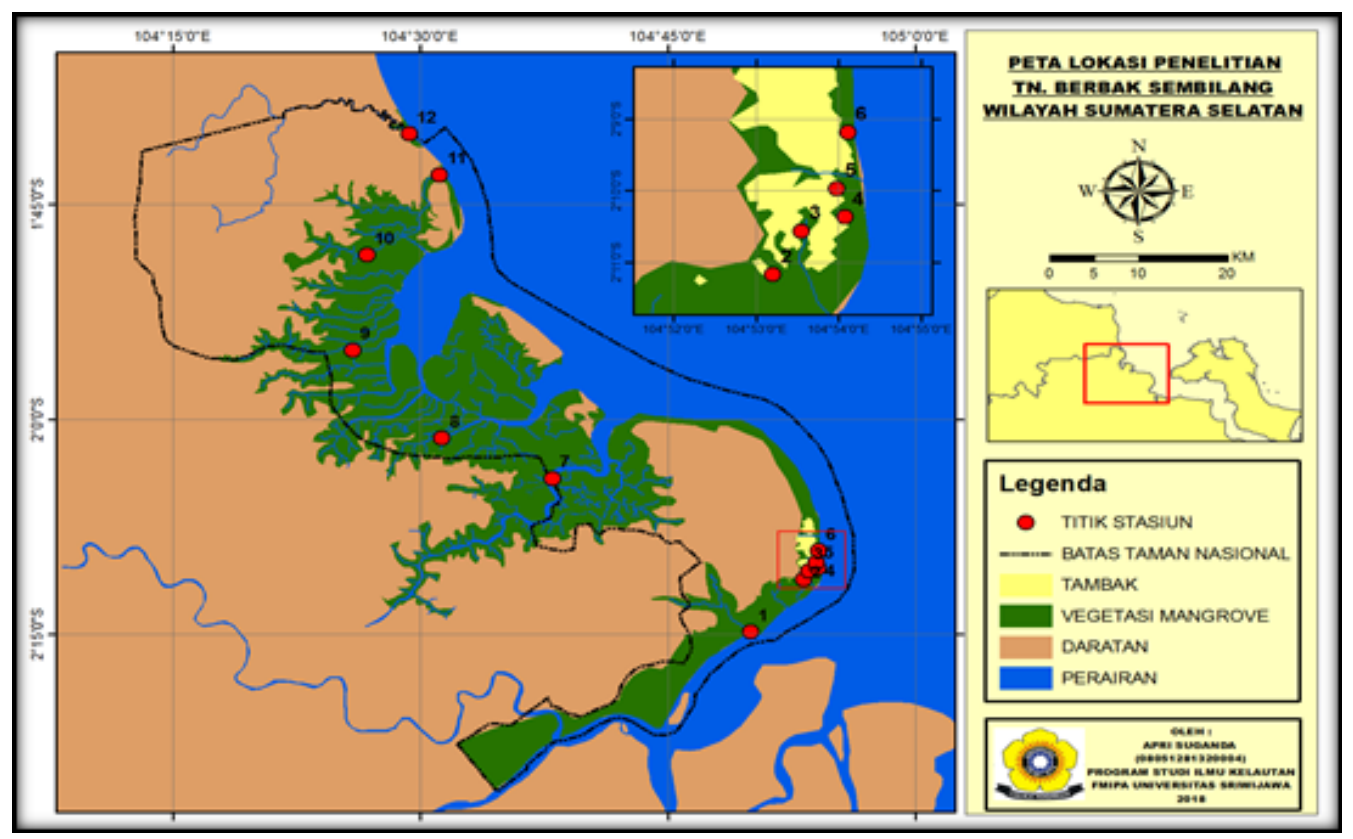

Gambar 1. Lokasi penelitian di Kawasan mangrove Taman Nasional Berbak Sembilang Wilayah Sumatera Selatan.

Figure 1. Research location in Berbak-Sembilang National Park, South Sumatera Area.

kategori pohon atau mangrove dewasa, yakni individu mangrove dengan Diameter at Breast Height $(\mathrm{DBH})>$ $4 \mathrm{~cm}$ (Ulqodry \& Sarno, 2017).

\section{Analisis Leaf Area Index (LAI)}

Estimasi karbon yang dapat diserap oleh mangrove melalui proses fotosintesis dianalisis dengan menggunakan metode Leaf Area Index (LAI) (Kathiresan, 2011). Metode ini melakukan pengukuran terhadap intensitas cahaya matahari yang diserap oleh kanopi mangrove. Untuk mengetahui berapa besar serapan kanopi terhadap intensitas cahaya matahari harus dilakukan pengukuran nilai intensitas cahaya matahari yang ada di bawah atau di dalam kanopi (I) dan Intensitas cahaya di atas atau di luar kanopi (I0 $\neg)$. Intensitas cahaya pada kanopi di bawah dan di luar kanopi diukur menggunakan lux meter.

Perhitungan Leaf Area Index merupakan perbandingan luas tutupan kanopi pohon terhadap luas area (Sahu dan Kathiresan, 2019).

$$
\mathrm{LAI}=\frac{\log e\left(\frac{I}{I_{0}}\right)}{-k}
$$

dimana,

LAI $=$ Leaf Area Index $\left(\right.$ luas daun $\left.\left(\mathrm{m}^{2}\right)\right) /\left(\right.$ luas area $\left.\left(\mathrm{m}^{2}\right)\right)$

I = Intensitas cahaya di bawah kanopi

I0 = Intensitas cahaya di luar kanopi

$\mathrm{K}=$ Konstanta $(0,5)$
Setelah didapat nilai LAI perlu dikoreksi dengan cara (Clough et al., 1997):

LAI terkoreksi $=\mathrm{LAI} \times \cos \left(\frac{\alpha \times 3.141593}{180}\right)$

Di mana $\alpha$ adalah sudut zenith matahari. Nilai $\alpha$ dapat ditentukan dengan menginput data lintang, bujur, tanggal dan jam ketika pengambilan data kemudian di proses pada http://solardat.uoregon.edu/ SolarPositionCalculator.html

\section{Estimasi Serapan Karbon Melalui Proses Fotosintesis berdasarkan nilai LAI}

Pendugaan sink karbon dari serapan karbondioksida dilakukan dengan menggunakan metode LAI dan dilanjutkan dengan menghitung laju fotosintesis bersih dari tutupan kanopi. Perhitungan nilai fotosintesis bersih dari kanopi mangrove ini dianalisis sebagai berikut (Kathiresan, 2011):

$\mathrm{P}=\mathrm{LAI}$ terkoreksi $\mathrm{x} \varphi \mathrm{xt}$

dimana,

$\mathrm{P}=$ Fotosintesis bersih $(\mathrm{gr}-\mathrm{C} / \mathrm{m} 2 /$ hari $)$

LAI terkoreksi $=$ Leaf Area Index terkoreksi

$\Phi=$ Konstanta Laju fotosintesis $(0.216)(\mathrm{gr}-\mathrm{C} / \mathrm{m} 2)$

$\mathrm{t}=$ panjang hari siang 


\section{HASIL DAN PEMBAHASAN}

Komposisi dan Kerapatan Vegetasi Mangrove Dominan di TNBS Sumsel

Penelitian ini dibatasi pada jenis-jenis mangrove yang membentuk tegakan sejati, berukuran dewasa (DBH $>4 \mathrm{~cm}$ ), serta dominan ditemukan di lapangan dengan kerapatannya lebih dari 10 individu pohon/ha. Mangrove dominan yang ditemukan dari 3 kawasan di 12 titik sampling di TNBS Sumatera Selatan adalah 14 jenis, terdiri dari 12 jenis mangrove mayor dan 2 jenis mangrove minor.

Ke-14 jenis mangrove dominan tersebut adalah Avicennia alba, Avicennia lanata, Avicennia marina, Brugueria cylindrica, Bruguiera gymnorrhiza, Bruguiera parviflora, Bruguiera sexangula, Ceriops tagal, Excoecaria agaloccha, Rhizophora apiculata, Rhizophora mucronata, Rhizophora stylosa, Sonneratia alba, dan Xylocarpus granatum.

Kerapatan jenis mangrove dan sebarannya di setiap stasiun pengamatan disajikan dalam Tabel 1 dan Gambar 2.

Tingkat kerapatan pohon tertinggi dari tiga kawasan mangrove di TNBS Sumatera Selatan berada di Kawasan Tanah Pilih di Stasiun 11. Kerapatan total mangrove pada lokasi ini mencapai 2.200 ind/ha. Direktorat Bina Pesisir, Dirjen P3K DKP (2004) membuat lima kriteria penilaian terhadap kerapatan mangrove yakni sangat rapat $\geq 880 \mathrm{ind} / \mathrm{ha}$, rapat $\geq 660-<880 \mathrm{ind} / \mathrm{ha}$, sedang $\geq 330-<660$, jarang $\geq 110-<330 \mathrm{ind} / \mathrm{ha}$ dan sangat jarang $<110 \mathrm{ind} / \mathrm{ha}$.
Tabel 1. Total kerapatan individu tiap jenis mangrove dominan di TNBS Sumatera Selatan

Table 1. The individual density for each mangrove species

\begin{tabular}{lll}
\hline No & $\begin{array}{l}\text { Jenis Mangrove } \\
\text { Dominan }\end{array}$ & $\begin{array}{l}\text { Kerapatan } \\
\text { (ind/ha) }\end{array}$ \\
\hline 1 & Avicennia alba & 322 \\
2 & Avicennia lanata & 156 \\
3 & Avicennia marina & 3944 \\
4 & Bruguiera cylindrica & 656 \\
5 & Bruguiera gymnorrhiza & 844 \\
6 & Bruguiera parviflora & 122 \\
7 & Bruguiera sexangula & 333 \\
8 & Ceriops tagal & 111 \\
9 & Excoecaria agaloccha & 300 \\
10 & Rhizophora apiculata & 1911 \\
11 & Rhizophora mucronata & 1111 \\
12 & Rhizophora stylosa & 300 \\
13 & Sonneratia alba & 11 \\
14 & Xylocarpus granatum & 1222 \\
\hline
\end{tabular}

Berdasarkan pedoman tersebut sebagian besar kondisi mangrove yang ada di TN. Berbak Sembilang wilayah Sumatera Selatan berada dalam kondisi sangat rapat dan rapat. Jika dirata-ratakan, nilai kerapatan untuk 12 stasiun pengamatan adalah $945 \mathrm{ind} / \mathrm{ha}$, yang dapat dikategorikan sebagai sangat rapat.

Genus Avicennia dan Rhizophora mendominasi hampir seluruh daerah TNBS Sumatera Selatan. Kawasan TNBS yang sangat didominasi oleh substrat berlumpur diduga sangat mendukung pertumbuhan dan perkembangan jenis-jenis mangrove dari kedua genus ini. Menurut Sunarni et al. (2019), di Indonesia, substrat

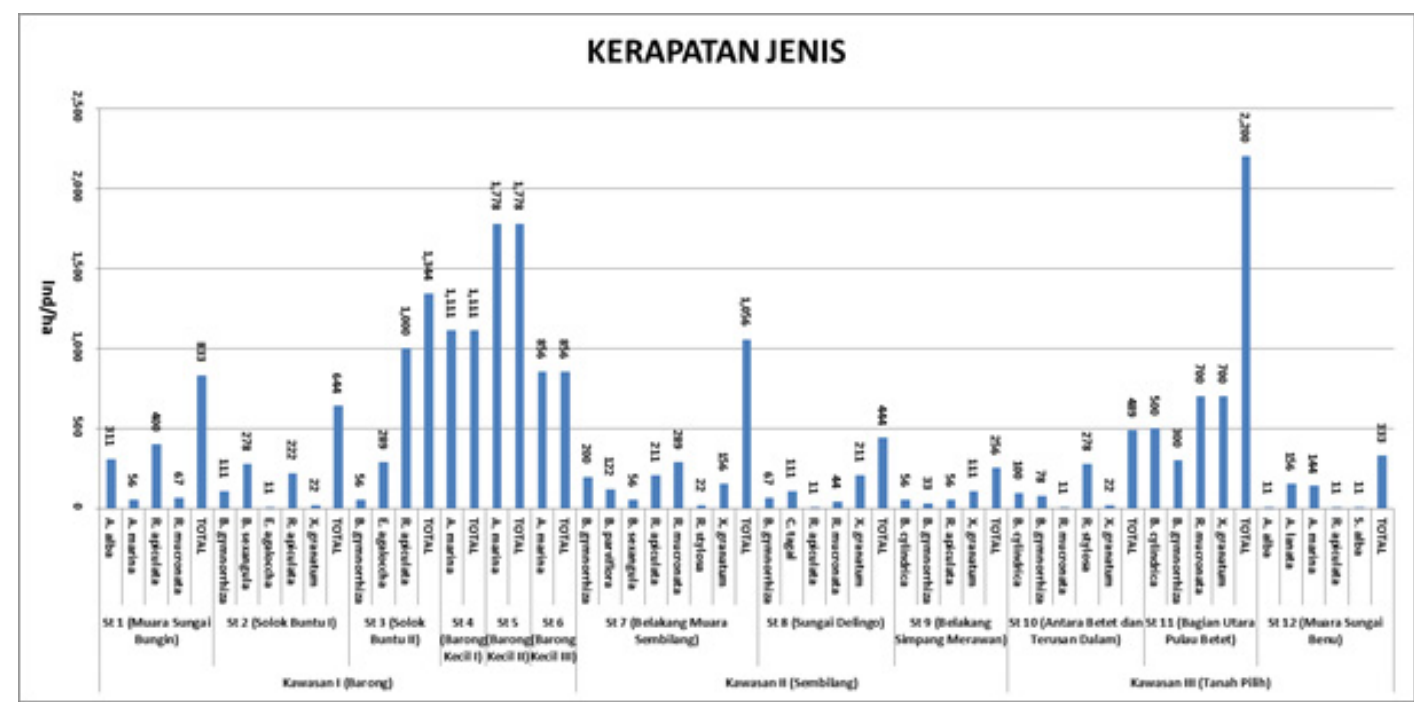

Gambar 2. Kerapatan jenis mangrove tingkat pohon di setiap stasiun pengamatan. Gambar 2. Mangrove density for tree level at each stations. 
berlumpur sangat baik untuk tegakan Avicennia dan Rhizophora.

Avicennia merupakan genus mangrove yang memiliki kemampuan toleransi terhadap kisaran salinitas yang paling luas dibandingkan dengan genus mangrove lainnya (Mcnae, 1968). Selain itu, lokasi sebagian besar kawasan TNBS Sumatera selatan berhadapan langsung dengan laut, sehingga jenis $A$. marina dapat tumbuh dengan baik. Menurut Noor et al. (2006), $A$ marina merupakan jenis mangrove pionir dan memiliki kemampuan menempati dan tumbuh pada berbagai habitat pasang-surut, bahkan pada lokasi asin sekalipun Selain itu, genus Avicennia juga menghasilkan buah atau benih dalam jumlah yang sangat besar dibandingkan kelompok mangrove lainnya.

Seperti hanya Avicennia, genus Rhizophora juga dapat menghasilkan propagul dalam jumlah yang cukup besar, sehingga sangat membantu dalam penyebarannya secara alami maupun untuk kegiatan restorasi. Menurut Komiyama et al. (1998), R. apiculata dan R. mucronata merupakan spesies penting dalam kegiatan restorasi di Asia Tenggara yang mampu menghasilkan propagul viviparous pada pohon induknya dalam jumlah besar. Selain itu, sistem perakaran tunjang Rhizophora yang kokoh dan masif menjadikannya memiliki kemampuan beradaptasi yang sangat baik terhadap substrat daerah pesisir yang sangat labil dan aksi gelombang dan arus yang kencang, dibandingkan jenis mangrove lainnya.

\section{Serapan Karbon Melalui Proses Fotosintesis Mangrove}

Tumbuhan melakukan fotosintesis untuk memenuhi kebutuhan hidup dan pertumbuhannya. Ketika melakukan fotosintesis tumbuhan akan menyerap gas karbondioksida yang ada di udara. Pada proses penyerapan ini unsur karbon akan dimanfaatkan oleh tumbuhan diantaranya menjadi biomasa. Total serapan karbon melalui proses fotosintesis pada tiap stasiun pengamatan di TNBS Sumatera Selatan disajikan pada Gambar 3.

Berdasarkan hasil penelitian yang telah dilakukan lokasi yang mampu menyerap karbon melalui proses fotosintesis tertinggi terdapat pada stasiun 11. Nilai serapan karbon pada stasiun ini mencapai 735,24 kg-C/ ha/jam. Tingginya nilai serapan karbon pada stasiun ini berbanding lurus dengan total nilai kerapatan pada stasiun tersebut. Vegetasi mangrove di kawasan penelitian tumbuh dengan baik, mengingat pada saat survei lapangan kondisi vegetasi mangrove tergolong mempunyai tingkat kerapatan lebat yang merata pada seluruh lokasi penelitian. Menurut Muhammad et al. (2014), kerapatan kanopi hutan (forest canopy density) dipengaruhi oleh peubah - peubah seperti basal area dan kerapatan tegakan.

Vegetasi mangrove yang ada di TNBS Sumatera Selatan memiliki kemampuan menyerap karbon melalui proses fotosintesis rata-rata $204,89 \mathrm{~kg}-\mathrm{C} /$ ha/hari. Hasil ini lebih tinggi dibandingkan dengan serapan karbon oleh kanopi mangrove di Peninsular, Malaysia hanya mampu menyerap karbon $155 \mathrm{~kg}-\mathrm{C} /$ ha/hari (Clough et al., 1997). Tetapi sedikit lebih rendah jika dibandingkan fotosintesis bersih kanopi mangrove di Tamil Nadu, Malaysia yang mencapai 215,2 kg-C/ha/hari (Sahu \& Kathiresan, 2019). Selain

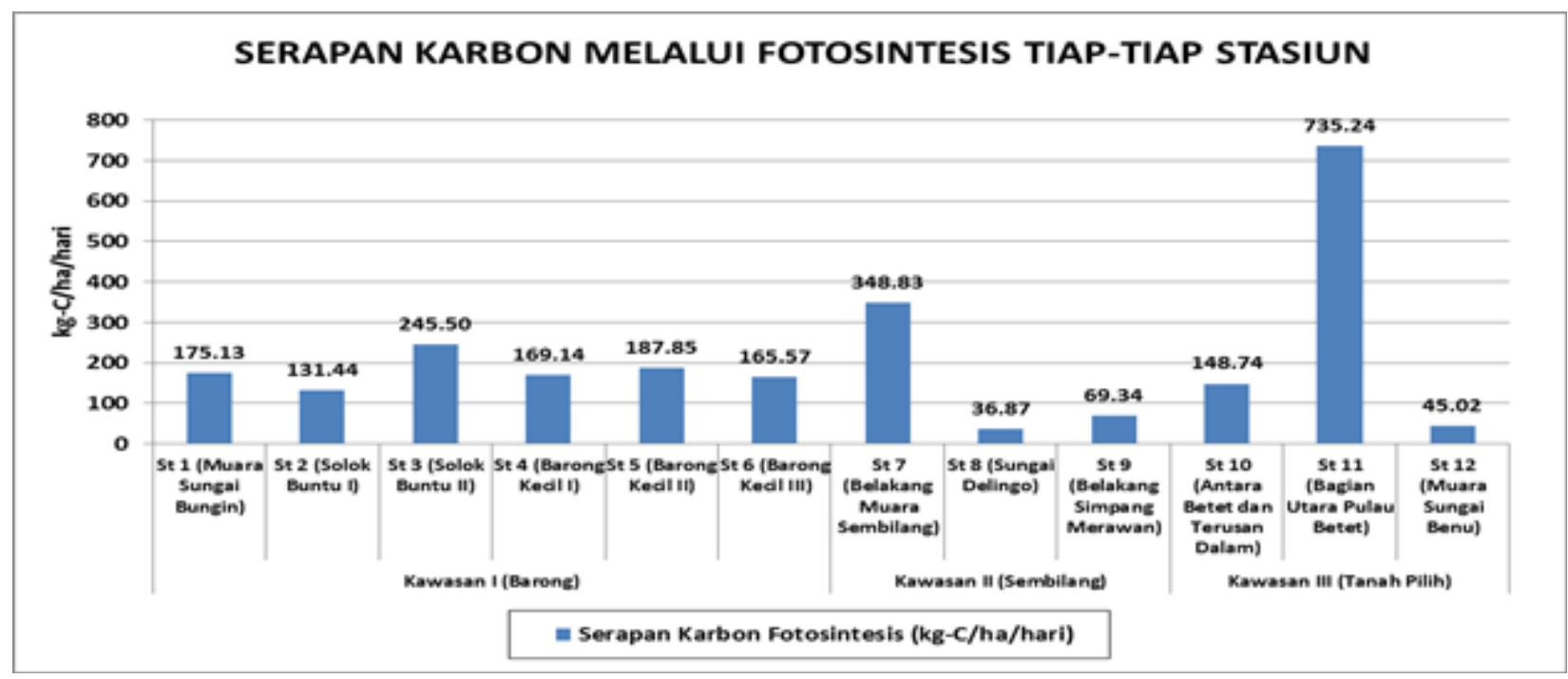

Gambar 2. Total serapan karbon melalui proses fotosintesis pada tiap stasiun pengamatan di TNBS Sumatera Selatan. Gambar 2. Total amount of Carbon sink by photosinthesis mechanism at eah stations in BSNP South Sumatera.

Estimasi Serapan Karbon Mangrove Melalui Proses Fotosintesis di Taman Nasional Berbak - Sembilang - Tengku Zia Ulqodry, Apri Suganda, Andi Agussalim, Riris Aryawati, \& Afan Absori 
Tabel 2. Total kerapatan individu tiap jenis mangrove dominan di TNBS Sumatera Selatan

Table 2. The individual density for each mangrove species

\begin{tabular}{lllll}
\hline No & $\begin{array}{l}\text { Jenis } \\
\text { Mangrove }\end{array}$ & $\begin{array}{l}\text { Jumlah } \\
\text { tegakan }\end{array}$ & $\begin{array}{l}\text { Total serapan karbon } \\
\text { per komunitas } \\
\text { (kg-C/ha/hari) }\end{array}$ & $\begin{array}{l}\text { Total serapan karbon } \\
\text { per individu } \\
\text { (kg-C/ha/hari) }\end{array}$ \\
\hline 1 & A. alba & 29 & 69,01 & 2,38 \\
2 & A. lanata & 14 & 17,09 & 1,22 \\
3 & A. marina & 355 & 553,37 & 1,56 \\
4 & B. cylindrica & 19 & 208,07 & 10,95 \\
5 & B. gymnorrhiza & 52 & 239,33 & 4,60 \\
6 & B. parviflora & 11 & 41,23 & 3,75 \\
7 & B. sexangula & 30 & 71,78 & 2,39 \\
8 & C. tagal & 10 & 9,98 & 1,00 \\
9 & E. agaloccha & 27 & 53,90 & 2,00 \\
10 & R. apiculata & 172 & 401,99 & 2,34 \\
11 & R. mucronata & 44 & 356,05 & 8,09 \\
12 & R. stylosa & 27 & 95,08 & 3,52 \\
13 & S. alba & 1 & 1,43 & 6,43 \\
14 & X. granatum & 54 & 340,37 & \\
\hline
\end{tabular}

Sumber: Hasil pengukuran

karena komposisi mangrove yang berbeda, perbedaan ini juga dapat disebabkan oleh kondisi di tiap kawasan mangrove yang juga berbeda-beda. Menurut Ulqodry et al. (2014), mangrove merupakan tumbuhan C3 yang memiliki perbedaan sensitifitas dan kapasitas fotosintesis yang berbeda pada kondisi lingkungan yang berbeda dan spesies yang berbeda. Perbedaan lingkungan tersebut diantaranya intensitas cahaya, salinitas, suhu dan pasang surut.

Kemampuan tiap jenis mangrove di TNBS dalam menyerap karbon melalui proses fotosintesis menunjukan kontribusi yang berbeda antara dalam skala komunitas dengan secara individual (Tabel 2).

Nilai serapan karbon melalui proses fotosintesis tertinggi secara bersama-sama adalah pada komunitas A. marina $(553,43 \mathrm{~kg}-\mathrm{C} / \mathrm{ha} /$ hari $)$, sedangkan per individu dengan rata-rata tertinggi ditemukan pada jenis $B$. cylindrica $(10,95 \mathrm{~kg}-\mathrm{C} / \mathrm{ha} / \mathrm{hari})$. Namun nilai serapan karbon melalui proses fotosintesis terendah secara bersama-sama adalah pada komunitas $S$. alba (1,43 kg-C/ha/hari), sedangkan per individu mangrove terendah ditemukan pada jenis C. tagal $(1,00 \mathrm{~kg}-\mathrm{C} / \mathrm{ha} /$ hari).

Pada level individu mangrove, kemampuan fotosintesis mangrove sangat dipengaruhi oleh banyak faktor, diantaranya kandungan klorofil (Evans, 1989), kerapatan stomata, ukuran stomata dan konduktansi stomata (Xuan et al., 2011), laju transpirasi (Kitaya et al., 2002), dan kapasitas biokimia daun (Sharkey, 1985).

\section{KESIMPULAN DAN SARAN}

Dari sisi kemampuan serapan karbon melalui fotosintesis, jenis A. marina, $R$. apiculata dan $B$. cylindrica dianjurkan sebagai tanaman restorasi dengan tujuan peningkatan sink karbon di kawasan mangrove TNBS Sumatera Selatan.

\section{UCAPAN TERIMA KASIH}

Penulis mengucapkan terima kasih kepada Bapak Taher, Bapak Alex, Fadly, Andreas, dan Jovi yang telah membantu selama kegiatan pengukuran di lapangan. Penulis juga mengucapkan terima kasih kepada Kantor Balai Taman Nasional Berbak-Sembilang, RISTEKDIKTI dan Universitas Sriwijaya yang telah memberi dukungan terhadap penelitian ini.

\section{DAFTAR PUSTAKA}

Clough, B. F., Ong, J. E., \& Gong, W. K. (1997). Estimating Leaf Area Index and Photosynthetic Production in Canopies of The Mangrove Rhizophpra apiculata. Marine Ecology Progress Series, 159, 185-292. 
Cui, X., Liang J., Lua W., Chen H., Liu F., Line, G., Xu, F., Luo, Y., \& Lin, G. (2018). Stronger Ecosystem Carbon Sequestration Potential of Mangrove Wetlands with Respect to Terrestrial Forests in Subtropical China. Agricultural and Forest Meteorology, 249, 71-80.

Direktorat Bina Pesisir-KKP. (2004). Pedoman Pengenalan Ekosistem Mangrove. Jakarta: Direktorat Jenderal Pesisir dan Pulau-pulau Kecil, Departemen Kelautan dan Perikanan.

Evans, J. R. (1989). Partition of Nitrogen between and within Leaves Grown under Different Irradiances. Australians Journal of Plant Physiology, 16, 533-548.

Kathiresan, K. (2011). Methods of Studying Mangrove. Tamil Nadu: Centre of Advanced Studies in Marine Biology, Annamalai University. 116-125.

Kepel, T. L., Ati, R. N., Rahayu, Y.P., \& Adi, N. S. (2018). Pengaruh Alih Fungsi Kawasan Mangrove pada Sifat Sedimen dan Kemampuan Penyimpanan Karbon. Jurnal Kelautan Nasional, 13 (3), 145153.

Kitaya, Y., Sumiyoshi, M., Kawabata, \& Y., Monji, N. (2002). Effect of Submergence and Shading of Hypocotyls on Leaf Conductance in Young Seedlings of the Mangrove Rhizophora stylosa. Trees, 16, 147-149.

Komiyama, A., Tanapermpool, P. B., Havanon, S., Maknual, C., Patanaponpaiboon, P., Sumida, A., Ohnishia, T. \& Kato, S. (1998). Mortality and Growth of Cut Pieces of Viviparous Mangrove (Rhizophora apiculata and R. mucronata) Seedlings in the Field Condition. Forest Ecology and Management, 112, 227-231.

Mac Nae, W. (1968). A General Account of Fauna and Flora of Mangrove Swamps and Forest in The Indowest-Pacific Region. Advance Marine Biology, 6,73-270.

Manuri, S., Putra, C. A. S., Imansyah, T., Purbopuspito, J., \& Warren, M.W. (2011). C-Stock Assessment of Mangrove Ecosystem at Sembilang National Park, South Sumatra, Indonesia. Technical Report, CIFOR, 1-19.

Muhammad, A., Prasetyo, L. B., \& Kartono, A. P.
(2014). Pemetaan Perubahan Forest Canopy Density di KPH Kuningan. Makalah disajikan dalam Seminar Nasional Penginderaan Jauh 2014, Bogor: DKSHE, Institut Pertanian Bogor.

Noor, Y. R., Khazali, M., \& Suryadiputra INN. (2006). Panduan Pengenalan Mangrove di Indonesia. Bogor: Wetlands international.

Okimoto, Y., Nose, A., Oshima, K., Tateda, Y., \& Ishii, T. (2013). A Case Study for an Estimation of Carbon Fixation Capacity in The Mangrove Plantation of Rhizophora apiculata trees in Trat, Thailand. Forest Ecology and Management, 310, 1016-1026.

Prihadi, D. J., Riyantini, I., \& Ismail, M. R. (2018). Pengelolaan Kondisi Ekosistem Mangrove dan Daya Dukung Lingkungan Kawasan Wisata Bahari Mangrove di Karangsong Indramayu. Jurnal Kelautan Nasional,13(1), 53-64.

Sahu, S. K. \& Kathiresan, K. (2019). The Age and Species Composition of Mangrove Forest Directly Influence The Net Primary Productivity and Carbon Sequestration Potential. Biocatalysis and Agricultural Biotechnology, 20, 1-11.

Sarno, Ridho, M. R., Indriani, D. P., Harmida, \& Pancasari,A.R. (2020). Estimation of Bruguiera's Carbon Stock In Berbak and Sembilang National Park Banyuasin South Sumatera. Biovalentia, 6(1), 15-20.

Sharkey, T. D. (1985). Photosynthesis in intact leaves of C3 plants: physics, physiology and rate limitations. The Botanical Review, 51, 53-105.

Sunarni, Maturbongs, M. R., Arifin, T., \& Rahmania, R. (2019). Zonasi dan Struktur Komunitas Mangrove di Pesisir Kabupaten Merauke. Jurnal Kelautan Nasional,14(3), 165-178.

Suniada, K. I., \& Aden, L. Y. (2019). Pengaruh Perubahan Luas Hutan Mangrove terhadap Konsentrasi Total Suspended Matter (TSM) di Muara Perancak, Jembrana - Bali. Jurnal Kelautan Nasional, 14(1), 11-24.

Suwignyo, R. A., Ulqodry, T. Z., Sarno, \& Miyakawa, H., \& Tatang. (2012). Mangrove Plant Condition in The Greenbelt Area of Banyuasin Peninsula, Sembilang National Park, South Sumatra, 
Indonesia and Its Restoration Plan. Chiang Mai University Journal of Natural Sciences. 11, 123134.

Ulqodry, T. Z., Matsumoto, F., Okimoto, Y., Nose A., \& Zheng, S.H. (2014). Study on Photosynthetic Responses and Chlorophyll Fluorescence in Rhizophora mucronata Seedlings under Shade Regimes. Acta Physiologiae Plantarum, 36, 1903-1917.

Ulqodry, T. Z., Nose, A., \& Zheng, S.H. (2016). An Improved Method for The Simultaneous Determination of Photosynthetic $\mathrm{O}_{2}$ Evolution and $\mathrm{CO}_{2}$ Consumption in Rhizophora mucronata Leaves. Photosynthetica, 53, 152-157.

Ulqodry T. Z., \& Sarno. (2017). Konservasi Mangrove. Palembang: Unsri Press.

Xuan, X., Wang, Y., Ma, S., \& Ye, X. (2011) Comparisons of Stomatal Parameters between Normal and Abnormal Leaf of Bougainvillea spectabilis Willd. African Jornal Biotechnology, 10, 6973-6978. 